\title{
A Catering Model of Dividends and Share Repurchases
}

\author{
Yordying Thanatawee \\ Lecturer in Finance, Graduate School of Commerce, Burapha University \\ 169 Longhadbangsaen Road, Sansuk, Maung, Chonburi, Thailand, 20131 \\ Tel: (66)-38-394-900 E-mail: yordying@yahoo.com
}

Received: July 14, 2011

doi:10.5539/ijef.v4n1p120

\author{
Accepted: August 12, 2011 \\ Published: January 1, 2012 \\ URL: http://dx.doi.org/10.5539/ijef.v4n1p120
}

\begin{abstract}
This paper develops a theoretical model to demonstrate that the firm's payout/investment decision may be affected by the relative magnitude of dividend and repurchasing premia. The model shows that the manager of high-quality firm may pass up a positive NPV project in order to cater to investors' demand for dividends or share repurchases (adverse selection problem) if the catering premia are substantial. On the other hand, the manager of low-quality firm may have strong incentives to return free cash flows to shareholders if the catering premia are higher than the private benefits from investing in a negative NPV project. Under this case, the agency costs of free cash flows are mitigated.
\end{abstract}

Keywords: Dividends, Share repurchases, Catering, Adverse selection, Free cash flow, Private benefits

\section{Introduction}

In a frictionless market, Miller and Modigliani's (1961) dividend irrelevance theorem indicate that the vale of the firm is independent of the firm's payout policy, implying that dividends and share repurchases are perfect substitutes. However, DeAngelo and DeAngelo $(2006,2007)$ argue that, even in the perfect market, payout policy does matter in the same sense that investment policy does and propose that the dividend irrelevance principle be replaced with 'the full payout' principle. Specifically, they point out that MM derive dividend irrelevance theorem from a model that implicitly and artificially constrains firms to distribute $100 \%$ of free cash flow in every period. When firms are allowed to retain free cash flows, while holding the NPV of investment policy fixed, the payout policy is no longer irrelevant.

In practice, the payouts differently affect the firm's market value. For instance, in February 2006, UBS announced that its net profit in the fourth-quarter of 2005 more than tripled and it would increase its payout to shareholders to 3.80 francs a share from 3.00 francs a share in 2004 and buy back as much as an additional five billion francs of shares after a buy back valued at 3.6 billion francs. However, UBS shares fell 1.50 francs, or $1.1 \%$, after the announcement. Analysts reasoned that "investors were disappointed that UBS hadn't increased its dividend even further." (The Wall Street Journal, February $15^{\text {th }}, 2006$ ).

Therefore, as demonstrated by the above article, the payout policy is not irrelevant.In the case of UBS, its shareholders appear to exhibit high demand for dividends. Considering the investor demand for dividends as a key determinant for corporate payout policy, Baker and Wurgler $(2004 a, b)$ propose a catering theory of dividends, stating that manager's decision to pay dividends is driven by the premium investors place on dividend paying firms. That is, managers cater to investors by paying dividends when investors put a premium on dividend payers, and by not paying dividends when investors prefer non dividend payers. They develop a model in which the manager trades off between a short-run stock price affected by investor demand for dividends and a long-run fundamental value determined by investment policy. The model predicts that the propensity to pay dividends is increasing in the dividend premium, the difference between the current stock prices of payers and nonpayers, and decreasing in the fundamental cost of dividends (e.g., costly external finance or taxes).

Fairchild and Zhang (2005) further develop Baker and Wurgler's (2004a, b) model, incorporating the repurchasing premium placed by investors as an important factor the managers consider in issuing their payout policy. Their model demonstrates that the firm's incentives to cater trough dividends or repurchases, or to retain cash flows to invest in positive NPV project depends on the manager's time horizon and the relative magnitude of dividend and repurchasing premia.

Ferris et al. (2006) investigate whether U.K. firms have lower propensity to pay dividends. They find that the number of U.K. firms paying dividends declines from $75.9 \%$ in 1988 to $54.5 \%$ in 2002 and that the number of new 
lists paying dividends declines from $60.2 \%$ to $28.6 \%$ during the same period. Controlling for firm size and profitability, they find that the decreases in dividend payers appear to be concentrated over the 1998-2002 period. To explain this change in dividend policies, Ferris et al. examine dividend premium of U.K. firms and find that catering incentives appeared to shift in the U.K. during the late 1990s. They conclude that this change in catering incentives most likely explain why fewer U.K. firms pay dividends.

Li and Lie (2006) extend Baker and Wurgler's (2004a) dividend catering model by including dividend increases and decreases. They argue that while Baker and Wurgler's (2004a) model might explain why some firms initiate or omit dividends, it cannot explain why firms change dividend level. In addition, insignificant relationship between announcement returns and dividend premiums in Baker and Wurgler (2004a) casts doubts about the validity of the catering theory. Consequently, $\mathrm{Li}$ and Lie assume that investors categorize firms into groups not only on whether they pay dividends but also on the dividend level.Li and Liefind that both the probability of dividend increases and decreases and the magnitude of dividend changes are related to dividend premium. In particular, when the dividend premium is high, firms are more likely to increase dividend and when the dividend premium is low, firms are more likely to decrease dividends and repurchase shares. Moreover, they find that the announcement returns for dividend increases are positively related to the dividend premium while the announcements returns for dividend decreases are negatively related to the dividend premium.

Denis and Osobov (2008) examine cross-sectional and time-series evidence on the propensity to pay dividends in several developed financial markets (the U.S., Canada, the U.K., Germany, France, and Japan) over the period 1989-2002. They test the catering theory by examining the relation between the propensity to pay dividends and the Baker and Wurgler's (2004a, b) dividend premium. Their evidence, however, fails to provide much support for the catering theory of dividends outside the U.S.

In a recent study, Ferris, Jayaraman, and Sabherwal (2009) test the catering theory of dividends across a sample of twenty-three countries. They find that, compared with that in civil law countries, dividend policy in common law countries is more driven by investor's demand for dividends because shareholders in common law countries have a higher level of legal protection, requiring the managers to be more responsive to investor's demand for dividends while, in civil law countries, the managers are less responsive to minority shareholders' demand because they are disciplined by large controlling shareholders who have less interest in exploring the market misevaluations of their firms' stock prices due to dividend policy.

Since the seminal papers of Baker andWurgler (2004a, b), the dividend catering premium has received a considerable attention as a factor affecting corporate payout policy. However, only does the work of Fairchild and Zhang (2005) consider the significance of repurchasing premium. In this paper, I extend Fairchild and Zhang's (2005) model by developing a model in which the managers of two firm types, a high-quality firm and a low-quality firm, use the corporate cash flows to pay dividends, repurchase shares, or invest in the new project. I focus on the case where the high-quality type has a positive NPV project available while the low-quality type has a negative NPV project available.

The model demonstrates that a myopic manager may pass up a positive NPV project in order to cater to investor demand for dividends or share repurchases. Therefore, paying out cash flows create adverse selection problem under this case. On the other hand, the modeldemonstrates that if the private benefits from investment are large enough, the manager may have a strong incentive to invest in a value-destroying project. Hence, it is more efficient for the low-quality firm to return cash flows to shareholders by paying dividends or repurchasing shares rather than invest in a negative NPV project.

The rest of this paper is organized as follows. Section 2 outlines the catering model of manager's payout/investment decision. Section 3 analyzesthe managerial payoffs. Section 4 analyzes the equilibrium outcomes. Section 5 concludes the paper.

\section{The Model}

Consider a three-period economy consisting of two all-equity firms whose types $i=\{H, L\}$, where $H$ denotes a high-quality type and $L$ denotes a low-quality type. The interest rate is zero and all participants are risk-neutral in this economy.

Date 0 : Each firm $i$ has a one-period project in place, which will generate a cash flow of $Y$ for certainty at date 1, and also a three-period project, which may succeed or fail with equal probability. If it succeeds, it will generate a date-3 cash flow of $Z^{H}$; if it fails, it will generate a date-3 cash flow of $Z^{L}$, where $Z^{H}>Z^{L}$ and $\frac{Z^{H}+Z^{L}}{2}=\bar{Z}$. The 
market cannot observe the firm types, and it thus assigns equal probability to each firm being $H$ or $L$. Hence, the market values of both firms at this date are the same: $V_{0 H}=V_{0 L}=I+\bar{Z}$.

Date 1: A new project becomes available. This project requires an investment $I=Y$, which means the manager must use all cash flow from the one-period project to finance this new project. This new project will provide a date 2 cash flow $X^{H}$ for firm $H$ and $X^{L}$ for firm $L$, where $X^{H}>I>X^{L}$. That is, firm $H$ has a positive NPV project available whereas firm $L$ has a negative NPV project available for investment. It is assumed that there is information asymmetry between managers and investors regarding the availability of this project. Specifically, investors do not expect the firms to reinvest the cash flow $I$ in any real project. Rather, they expect managers to pay dividends or repurchase shares. Therefore, following Baker and Wurgler (2004a, b), it is assumed that investors place a premium on dividend paying firms. In addition, as in Fairchild and Zhang (2005), investors also place a premium on repurchasing firms. Therefore, if managers decide not to invest in the new project, the value of the firm at date 1 is $V_{1}=V_{0}+\lambda_{1}$, where $\lambda_{1}$ represents the date 1 catering premium. Further, it is assumed that investors react immediately to dividend announcements but respond with time lag to share repurchase announcements. Therefore, there is no market reaction at date 1 if the manager decides to repurchase shares $\left(\lambda_{1}^{R}=0\right)$ (Note 1).Further, the repurchasing premium at date 2 is assumed to be higher than the dividend premium at date $1\left(\lambda_{2}^{R}>\lambda_{1}^{D}\right)$ (Note 2 ).

The manager makes his date 1 reinvestment/payout decision to maximize his payoff $M_{i}$, which is specified as

$$
M_{i}=\alpha V_{1}+(1-\alpha) V_{2}+B
$$

where $V_{1}$ and $V_{2}$ are the expected market values of the firm at date 1 and date 2 respectively, $\alpha \in[0,1]$ represents the manager's date 1 compensation parameter, and $B \geq 0$ is the private benefits from investment.

The market's posterior beliefs as it observes the firms' strategy combination $\left(s_{H}, s_{L}\right)$, where $s_{i}=\{I, D, R\}$, are specified as follows:

a) Observing both firms playing identical strategies $(I, I),(D, D)$ or $(R, R)$, the market cannot distinguish the firm types and continues to assign equal probability to each firm being type $H$ or $L$.

b) Observing $(D, R)$ or $(R, D)$, the market does not update its beliefs but continues to assign equal probability to each firm being type $H$ or $L$.

c) Observing one firm invests in the new project while the other firm pays dividends or repurchases shares, the market believes that the firm investing in the new project is type $L$ and the other firm is type $H$.

The managers announce the investment/payout policies and receive date 1 compensation.

Date 2: If the managers invested in the new project at date 1, the cash flow is now realized. Nevertheless, investors do not update their beliefs regarding the probability of success or failure of the date 3 project (i.e., the investors believe that the cash flows will be used to pay dividends or repurchase shares). If the manager did not invest at date 1 but instead paid dividends or repurchased shares, the firm' market value increases to $V_{2}=V_{1}+\lambda_{2}$, where $\lambda_{2}$ represents the date 2 catering premium. Note that there is no dividend catering premium $\left(\lambda_{2}^{D}=0\right)$ at this date because the investors already placed the entire dividend premium at date 1 .

Date 3: The cash flow from the date 3 project is realized. All cash flows are returned to investors.

\section{Analysis of Managerial Payoffs}

In this catering game, each firm has three policy decisions: invest in the new project, pay dividends, or repurchase shares, denoted by $s_{i}=\{I, D, R\}$ respectively. Therefore, there are nine strategy combinations $\left(s_{H}, s_{L}\right)$ to be analysed as follows.

a) Both firms invest in the new project

At date 1, the market observes $(I, I)$ and cannot separate the firm types. As a result, it does not react at date. Hence, the market values of both firms at date 1 are still the same as those at date 0 .

$$
V_{1 H}=V_{1 L}=I+\bar{Z}
$$

At date 2, the cash flow from the date 1 investment is realized. The market continues to believe that the date 3 project will succeed or fail with equal probability. Hence, the market values of both firms are

$$
V_{2 H}=\bar{Z}+X^{H}
$$




$$
V_{2 L}=\bar{Z}+X^{L}
$$

Substituting firm market values at date 1 and date 2 in equation (1) yields

b) Both firms pay dividends

$$
\begin{gathered}
M_{H}=\alpha(I+\bar{Z})+(1-\alpha)\left(\bar{Z}+X^{H}\right)+B \\
M_{L}=\alpha(I+\bar{Z})+(1-\alpha)\left(\bar{Z}+X^{L}\right)+B
\end{gathered}
$$

At date 1 , the market observes $(D, D)$ and cannot separate the firm types. However, the investors place the catering premium, $\lambda_{1}{ }^{D}$, to the firms paying dividends. Hence, the market values of both firms are

$$
V_{1 H}=V_{1 L}=I+\bar{Z}+\lambda^{D}
$$

At date 2, the market continues to believe that the date 3 project will succeed or fail with equal probability. Hence, the market values of both firms are

$$
V_{2 H}=V_{2 L}=I+\bar{Z}+\lambda^{D}
$$

Substituting firm market values at date 1 and date 2 in equation (1) yields

$$
\begin{gathered}
M_{H}=I+\bar{Z}+\lambda^{D} \\
M_{L}=I+\bar{Z}+\lambda^{D}
\end{gathered}
$$

c) Both firms repurchase shares

Observing $(R, R)$, the market cannot distinguish the firm types. However, it reacts to the share repurchase announcement with time lag. Therefore, the market values of both firms at date 1 are still the same as those at date 0 .

$$
V_{1 H}=V_{1 L}=I+\bar{Z}
$$

At date 2, the market does not update its belief regarding the probability of success of the date 3 project. However, it places the catering premium for repurchasing firms. Thus, the market values of both firms are

$$
V_{2 H}=V_{2 L}=I+\bar{Z}+\lambda^{R}
$$

Substituting firm market values at date 1 and date 2 in equation (1) yields

$$
\begin{aligned}
& M_{H}=\alpha(I+\bar{Z})+(1-\alpha)\left(I+\bar{Z}+\lambda^{R}\right) \\
& M_{H}=\alpha(I+\bar{Z})+(1-\alpha)\left(I+\bar{Z}+\lambda^{R}\right)
\end{aligned}
$$

d) Firm $H$ invests in the new project while firm $L$ pays dividends

The investors observe $(I, D)$ and incorrectly distinguish the firm types as $(L, H)$. Therefore, the market values of both firms at date 1 are

$$
\begin{gathered}
V_{1 H}=I+Z^{L} \\
V_{1 L}=I+Z^{H}+\lambda^{D}
\end{gathered}
$$

At date 2, the cash flow from the date-1 project is realized for high-quality type. The market values of both firms are

$$
\begin{gathered}
V_{2 H}=Z^{L}+X^{H} \\
V_{2 L}=I+Z^{H}+\lambda^{D}
\end{gathered}
$$

Substituting firm market values at date 1 and date 2 in equation (1) yields

$$
\begin{gathered}
M_{H}=\alpha\left(I+Z^{L}\right)+(1-\alpha)\left(Z^{L}+X^{H}\right)+B \\
M_{L}=I+Z^{H}+\lambda^{D}
\end{gathered}
$$

e) Firm $H$ invests in the new project while firm $L$ repurchase shares

The investors observe $(I, R)$ and incorrectly distinguish the firm types as $(L, H)$. Therefore, the market values of both firms at date 1 are

$$
\begin{aligned}
& V_{1 H}=I+Z^{L} \\
& V_{1 L}=I+Z^{H}
\end{aligned}
$$

At date 2 , the cash flow from the date 1 project is realized for the high-quality type. The market values of both firms are

$$
V_{2 H}=Z^{L}+X^{H}
$$




$$
V_{2 L}=I+Z^{H}+\lambda^{R}
$$

Substituting firm market values at date 1 and date 2 in equation (1) yields

$$
\begin{gathered}
M_{H}=\alpha\left(I+Z^{L}\right)+(1-\alpha)\left(Z^{L}+X^{H}\right)+B \\
M_{L}=\alpha\left(I+Z^{H}\right)+(1-\alpha)\left(I+Z^{H}+\lambda^{R}\right)
\end{gathered}
$$

f) Firm $H$ pays dividends while firm $L$ invests in the new project

The investors observe $(D, I)$ and correctly distinguish the firm types as $(H, L)$. Therefore, the market values of both firms at date 1 are

$$
\begin{gathered}
V_{1 H}=I+Z^{H}+\lambda^{D} \\
V_{1 L}=I+Z^{L}
\end{gathered}
$$

At date 2 , the cash flow from the date 1 project is realized for low-quality type. The market values of both firms are

$$
\begin{gathered}
V_{2 H}=I+Z^{H}+\lambda^{D} \\
V_{2 L}=Z^{L}+X^{L}
\end{gathered}
$$

Substituting firm market values at date 1 and date 2 in equation (1) yields

$$
\begin{gathered}
M_{H}=I+Z^{H}+\lambda^{D} \\
M_{L}=\alpha\left(I+Z^{L}\right)+(1-\alpha)\left(Z^{L}+X^{L}\right)+B
\end{gathered}
$$

g) Firm $H$ repurchases shares while firm $L$ invests in the new project

The investors observe $(R, I)$ and correctly distinguish the firm types as $(H, L)$. Thus, the market values of both firms at date 1 are

$$
\begin{gathered}
V_{1 H}=I+Z^{H} \\
V_{1 L}=I+Z^{L}
\end{gathered}
$$

At date 2 , the cash flow from the date 1 project is realized for low-quality type. The values of both firms are

$$
\begin{gathered}
V_{2 H}=I+Z^{H}+\lambda^{R} \\
V_{2 L}=Z^{L}+X^{L}
\end{gathered}
$$

Substituting firm market values at date 1 and date 2 in equation (1) yields

$$
\begin{gathered}
M_{H}=\alpha\left(I+Z^{H}\right)+(1-\alpha)\left(I+Z^{H}+\lambda^{R}\right) \\
M_{L}=\alpha\left(I+Z^{L}\right)+(1-\alpha)\left(Z^{L}+X^{L}\right)+B
\end{gathered}
$$

h) Firm $H$ repurchases shares while firm $L$ pays dividends

Observing $(R, D)$, the investors do not distinguish the firm types and thus do not update the probability of success of the date 3 project. However, they attach the catering premium immediately to dividend paying firm and with time lag to repurchasing firm. Thus, the market values of both firms at date 1 are

$$
\begin{gathered}
V_{1 H}=I+\bar{Z} \\
V_{1 L}=I+\bar{Z}+\lambda^{D}
\end{gathered}
$$

At date 2, the values of both firms are

$$
\begin{aligned}
& V_{2 H}=I+\bar{Z}+\lambda^{R} \\
& V_{2 L}=I+\bar{Z}+\lambda^{D}
\end{aligned}
$$

Substituting firm market values at date 1 and date 2 in equation (1) yields

$$
\begin{gathered}
M_{H}=\alpha I+\bar{Z}+(1-\alpha)\left(I+\bar{Z}+\lambda^{R}\right) \\
M_{L}=I+\bar{Z}+\lambda^{D}
\end{gathered}
$$

i) Firm $H$ pays dividends while firm $L$ repurchases shares

Observing $(D, R)$, the investors do not distinguish the firm types and thus do not update the probability of success of the date 3 project. However, they attach the catering premium immediately to dividend paying firm and with time lag to repurchasing firm. Thus, the market values of both firms at date 1 are

$$
V_{1 H}=I+\bar{Z}+\lambda^{D}
$$




$$
V_{1 L}=I+\bar{Z}
$$

At date 2, the values of both firms are

$$
\begin{aligned}
& V_{2 H}=I+\bar{Z}+\lambda^{D} \\
& V_{2 L}=I+\bar{Z}+\lambda^{R}
\end{aligned}
$$

Substituting firm market values at date 1 and date 2 in equation (1) yields

$$
\begin{gathered}
M_{H}=I+\bar{Z}+\lambda^{D} \\
M_{L}=\alpha(I+\bar{Z})+(1-\alpha)\left(I+\bar{Z}+\lambda^{R}\right)
\end{gathered}
$$

\section{Equilibrium Analysis}

The normal-form of this dividend and repurchase catering game is illustrated in Figure 1 below.

\section{Insert Figure 1Here}

Having obtained all the managerial payoffs, the strategic equilibria of both firms can now be analyzed. I focus on the case where $X^{H}>I>X^{L}$. The results are as follows:

Lemma 1Regardless of firm H's strategies, firm L's best responses are as follows:

a) Invests in the new project if $B \geq\left(\frac{Z^{H}-Z^{L}}{2}\right)+\lambda^{D}-(1-\alpha)\left(X^{L}-I\right)$ and

$$
B \geq\left(\frac{Z^{H}-Z^{L}}{2}\right)+(1-\alpha) \lambda^{R}-(1-\alpha)\left(X^{L}-I\right)
$$

b) Pays dividends if $B<\left(\frac{Z^{H}-Z^{L}}{2}\right)+\lambda^{D}-(1-\alpha)\left(X^{L}-I\right)$ and $\lambda^{D} \geq(1-\alpha) \lambda^{R}$;

c) Repurchases shares if $B<\left(\frac{Z^{H}-Z^{L}}{2}\right)+(1-\alpha) \lambda^{R}-(1-\alpha)\left(X^{L}-I\right)$ and $\lambda^{D}<(1-\alpha) \lambda^{R}$.

Proof: See Appendix.

Lemma 1 shows that firm $\mathrm{L}$ chooses to invest in a new project if the private benefits outweigh the loss from investment and the loss from separation. Its decision to pay dividends or repurchase shares is determined by the relative magnitudes of dividend and repurchasing premia as well asthe managerial compensation parameter.

Lemma 2Regardless of firm L's strategies, firm H's best responses are as follows:

a) Invests in the new project if $B>\left(\frac{Z^{H}-Z^{L}}{2}\right)+\lambda^{D}-(1-\alpha)\left(X^{H}-I\right)$ and

$$
B>\left(\frac{Z^{H}-Z^{L}}{2}\right)+(1-\alpha) \lambda^{R}-(1-\alpha)\left(X^{H}-I\right)
$$

b) Pays dividends if $B<\left(\frac{Z^{H}-Z^{L}}{2}\right)+\lambda^{D}-(1-\alpha)\left(X^{H}-I\right)$ and $\lambda^{D}>(1-\alpha) \lambda^{R}$;

c) Repurchase shares if $B<\left(\frac{Z^{H}-Z^{L}}{2}\right)+(1-\alpha) \lambda^{R}-(1-\alpha)\left(X^{H}-I\right)$ and $\lambda^{D}<(1-\alpha) \lambda^{R}$.

Proof: See Appendix.

Lemma 2 demonstrates that firm $\mathrm{H}$ chooses to invest in the new project if the net cash flows from investment plus the private benefitsare higher than both the sum of degree of information asymmetry and dividend premium, and the sum of the degree of information asymmetry and repurchasing premium. Firm H's decision to pay dividends or repurchase shares is determined by the relative magnitudes of dividend premium and repurchasing premiumas well as the managerial compensation parameter. 
Proposition 1: From lemma 3 and lemma 4, I can derive the effects of private benefits on equilibrium outcomes as follows:

a) If $\lambda^{D}<(1-\alpha) \lambda^{R}$ and:

i) $B \geq\left(\frac{Z^{H}-Z^{L}}{2}\right)+\lambda^{D}-(1-\alpha)\left(X^{L}-I\right)$, there exists a unique pooling equilibrium $(I, I)$

ii) $\left(\frac{Z^{H}-Z^{L}}{2}\right)+\lambda^{D}-(1-\alpha)\left(X^{H}-I\right) \leq B<\left(\frac{Z^{H}-Z^{L}}{2}\right)+\lambda^{D}-(1-\alpha)\left(X^{L}-I\right)$, there exists a unique separating equilibrium $(I, D)$

iii) $B<\left(\frac{Z^{H}-Z^{L}}{2}\right)+\lambda^{D}-(1-\alpha)\left(X^{H}-I\right)$, there exists a unique pooling equilibrium $(D, D)$

b) If $\lambda^{D}<(1-\alpha) \lambda^{R}$ and:

i) $B \geq\left(\frac{Z^{H}-Z^{L}}{2}\right)+(1-\alpha) \lambda^{R}-(1-\alpha)\left(X^{L}-I\right)$, there exists a unique pooling equilibrium $(I, I)$

ii) $\left(\frac{Z^{H}-Z^{L}}{2}\right)+\lambda^{D}-(1-\alpha)\left(X^{H}-I\right) \leq B<\left(\frac{Z^{H}-Z^{L}}{2}\right)+\lambda^{D}-(1-\alpha)\left(X^{L}-I\right)$, there exists a unique separating equilibrium $(I, R)$

iii) $B<\left(\frac{Z^{H}-Z^{L}}{2}\right)+(1-\alpha) \lambda^{R}-(1-\alpha)\left(X^{H}-I\right)$, there exists a unique pooling equilibrium $(R, R)$

\section{Conclusion}

This paper considers the case where the managers of two firm types, a high-quality firm and a low-quality firm, decide whether to use the free cash flow to pay dividends, repurchase shares, or invest in the new project. The effects of the manager's dividend and repurchase catering motives are analyzed in this model. It is assumed that the investors place both dividend premium and repurchase premium on dividend-paying firm and repurchasing firm respectively and that they respond immediately to dividend announcements but with time lag to share repurchase announcements.

The results show that the firm's payout policy depends on: (1) the relative magnitude of dividend and repurchasing premia; (2) the gain/loss from investment; (3) the manager's time horizon; (4) the degree of information asymmetry; and (5) the private benefits from investment.Both adverse selection and moral hazard problems are addressed in this model. Specifically, the high-quality firm may pass up a positive NPV project if the catering premia are sufficiently high (adverse selection problem). On the other hand, the low-quality firm has strong incentive to return the free cash flow to shareholders if the catering premia are higher than the private benefits from investing in a negative NPV project. Hence, the agency costs of free cash flows are mitigated in the latter case.

\section{References}

Barberis, N., Shleifer, A., \& Vishny, R. (1998). A model of investor sentiment. Journal of Financial Economics, 49, 307-343. http://dx.doi.org/10.1016/S0304-405X(98)00027-0

Baker, M., \& Wurgler, J. (2004a). A catering theory of dividends. Journal of Finance, 59, 1125-1165, http://dx.doi.org/10.1111/j.1540-6261.2004.00658.x

Baker, M., \& Wurgler, J. (2004b). Appearing and disappearing dividends: the link to catering incentives. Journal of Financial Economics, 73, 271-288, http://dx.doi.org/10.1016/j.jfineco.2003.08.001

Daniel, K., Hirshleifer, D., \& Subrahmanyam, A. (1998).Investor psychology and security market under- and over-reactions. Journal of Finance, 53, 1839-1885, http://dx.doi.org/10.1111/0022-1082.00077

DeAngelo, H., \& DeAngelo, L. (2006).The irrelevance of the MM dividend irrelevance theorem. Journal of Financial Economics, 79, 293-315, http://dx.doi.org/10.1016/j.jfineco.2005.03.003 
DeAngelo, H., \& DeAngelo, L. (2007). Payout policy pedagogy: what matters and why. European Financial Management, 13, 11-17, http://dx.doi.org/10.1111/j.1468-036X.2006.00283.x

Denis, D.J., \& Osobov, I. (2008). Why Do Firms Pay Dividends?International evidence on the determinants of dividend policy. Journal of Financial Economics, 89, 62-82, http://dx.doi.org/10.1016/j.jfineco.2007.06.006

Fairchild, R., \& Zhang, G. (2005).Repurchase and dividend catering, managerial myopia, and long-run value destruction.Working Paper Series, School of Management, University of Bath, UK.

Ferris, S.P., Sen, N., \& Yui, H.P. (2006). God saves the Queen and her dividends: corporate payouts in the United Kingdom. Journal of Business, 79, 1149-1173, http://dx.doi.org/10.1086/500672

Ferris, S.P., Jayaraman, N., \& Sabherwal, S. (2009). Catering effects in corporate dividend policy: the international evidence. Journal of Banking and Finance, 33, 1730-1738, http://dx.doi.org/10.1016/j.jbankfin.2009.04.005

Grullon, G., \& Michaely, R. (2004). The information content of share repurchase programs. Journal of Finance, 59, 651-680, http://dx.doi.org/10.1111/j.1540-6261.2004.00645.x

Ikenberry, D., Lakonishok, J., \& Vermaelen, T. (1995). Market underreaction to open market share repurchases. Journal of Financial Economics, 39, 181-208, http://dx.doi.org/10.1016/0304-405X(95)00826-Z

Ikenberry, D., Lakonishok, J., \& Vermaelen, T. (2000). Stock repurchases in Canada: performance and strategic trading. Journal of Finance, 55, 2373-2397, http://dx.doi.org/10.1111/0022-1082.00291

Li, W., \& Lie, E. (2006).Dividend changes and catering incentives. Journal of Financial Economics, 80, 293-308, http://dx.doi.org/10.1016/j.jfineco.2005.03.005

Miller M., \& Modigliani, F. (1961).Dividend policy, growth, and the valuation of shares. Journal of Business, 34, 411-433, http://dx.doi.org/10.1086/294442

\section{Notes}

Note 1 . This assumption greatly simplifies the analysis without changing the intuition of the model.

Note 2. This is empirically supported by Ikenberry, Lakonishok, and Vermaelen $(1995,2000)$ and Grullon and Michaely (2004), among others, who report that the market initially underreacts to open market share repurchases. The market underreaction to open market share repurchases can also be considered in the framework of behavioral finance. For example, market over- and under-reaction to corporate news features in the investor-sentiment model of Barberis, Shleifer and Vishny (1998), and the investor-psychological-bias model of Daniel, Hirshleifer and Subrahmanyam (1998).

\begin{tabular}{|c|c|c|c|}
\hline & $\mathrm{D}$ & $\mathrm{R}$ & I \\
\hline$D$ & (4), (5) & $(18),(19)$ & $(12),(13)$ \\
\hline $\mathrm{R}$ & (16), (17) & $(6),(7)$ & $(14),(15)$ \\
\hline I & $(8),(9)$ & $(10),(11)$ & $(2),(3)$ \\
\hline
\end{tabular}

Figure 1. Dividend and Share Repurchase Catering Game

\section{Appendix}

\section{Proof of Lemma 1}

Given that firm $H$ invests in the new project, (3), (9), and (11) are compared in order to find firm $L$ 's best responses.

$$
\begin{aligned}
& \text { (3) } \geq(9) \text { if } \bar{Z}+(1-\alpha)\left(X^{L}-I\right)+B \geq Z^{H}+\lambda^{D} \Rightarrow B \geq\left(\frac{Z^{H}-Z^{L}}{2}\right)+\lambda^{D}-\left((1-\alpha)\left(X^{L}-I\right)\right) \\
& \text { (3) } \geq \text { (11) if } \bar{Z}+(1-\alpha)\left(X^{L}-I\right)+B \geq Z^{H}+(1-\alpha) \lambda^{R} \Rightarrow B \geq\left(\frac{Z^{H}-Z^{L}}{2}\right)+(1-\alpha)\left(\lambda^{R}-\left(X^{L}-I\right)\right) . \\
& \text { (9) } \geq(11) \text { if } \lambda^{D} \geq(1-\alpha) \lambda^{R} \text {. }
\end{aligned}
$$


Given that firm $H$ pays dividends, (13), (5), and (19) are compared in order to find firm $L$ 's best responses.

$$
\begin{aligned}
& \text { (13) } \geq(5) \text { if } \bar{Z}+(1-\alpha)\left(X^{L}-I\right)+B \geq Z^{H}+\lambda^{D} \Rightarrow B \geq\left(\frac{Z^{H}-Z^{L}}{2}\right)+\lambda^{D}-\left((1-\alpha)\left(X^{L}-I\right)\right) . \\
& (13) \geq(19) \text { if } \bar{Z}+(1-\alpha)\left(X^{L}-I\right)+B \geq Z^{H}+(1-\alpha) \lambda^{R} \Rightarrow B \geq\left(\frac{Z^{H}-Z^{L}}{2}\right)+(1-\alpha)\left(\lambda^{R}-\left(X^{L}-I\right)\right) . \\
& \text { (5) } \geq(19) \text { if } \lambda^{D} \geq(1-\alpha) \lambda^{R} .
\end{aligned}
$$

Given that firm $H$ repurchases shares, (15), (17), and (7) are compared in order to find firm $L$ 's best responses.

$$
\begin{aligned}
& (15) \geq(17) \text { if } \bar{Z}+(1-\alpha)\left(X^{L}-I\right)+B \geq Z^{H}+\lambda^{D} \Rightarrow B \geq\left(\frac{Z^{H}-Z^{L}}{2}\right)+\lambda^{D}-\left((1-\alpha)\left(X^{L}-I\right)\right) . \\
& (15) \geq(7) \text { if } \bar{Z}+(1-\alpha)\left(X^{L}-I\right)+B \geq Z^{H}+(1-\alpha) \lambda^{R} \Rightarrow B \geq\left(\frac{Z^{H}-Z^{L}}{2}\right)+(1-\alpha)\left(\lambda^{R}-\left(X^{L}-I\right)\right) .
\end{aligned}
$$$$
(17) \geq(7) \text { if } \lambda^{D} \geq(1-\alpha) \lambda^{R} \text {. }
$$

\section{Proof of Lemma 2}

Given that firm $L$ invests in the new project, (2), (12), and (14) are compared in order to find firm $H$ 's best responses.

$$
\begin{aligned}
& \text { (2) } \geq(12) \text { if } \bar{Z}+(1-\alpha)\left(X^{H}-I\right)+B \geq Z^{H}+\lambda^{D} \Rightarrow B \geq\left(\frac{Z^{H}-Z^{L}}{2}\right)+\lambda^{D}-\left((1-\alpha)\left(X^{H}-I\right)\right) . \\
& (2) \geq(14) \text { if } \bar{Z}+(1-\alpha)\left(X^{H}-I\right)+B \geq Z^{H}+(1-\alpha) \lambda^{R} \Rightarrow B \geq\left(\frac{Z^{H}-Z^{L}}{2}\right)+(1-\alpha)\left(\lambda^{R}-\left(X^{H}-I\right)\right) . \\
& (12) \geq(14) \text { if } \lambda^{D} \geq(1-\alpha) \lambda^{R} .
\end{aligned}
$$

Given that firm $L$ pays dividends, (8), (4), and (16) are compared in order to find firm $H$ 's best responses.

(8) $\geq(4)$ if $\bar{Z}+(1-\alpha)\left(X^{H}-I\right)+B \geq Z^{H}+\lambda^{D} \Rightarrow B \geq\left(\frac{Z^{H}-Z^{L}}{2}\right)+\lambda^{D}-\left((1-\alpha)\left(X^{H}-I\right)\right)$.

(8) $\geq(16)$ if $\bar{Z}+(1-\alpha)\left(X^{H}-I\right)+B \geq Z^{H}+(1-\alpha) \lambda^{R} \Rightarrow B \geq\left(\frac{Z^{H}-Z^{L}}{2}\right)+(1-\alpha)\left(\lambda^{R}-\left(X^{H}-I\right)\right)$.

(4) $\geq(16)$ if $\lambda^{D} \geq(1-\alpha) \lambda^{R}$.

Given that firm $L$ repurchases shares, (10), (18), and (6) are compared in order to find firm $H$ 's best response.

$$
\begin{aligned}
& (10) \geq(18) \text { if } \bar{Z}+(1-\alpha)\left(X^{H}-I\right)+B \geq Z^{H}+\lambda^{D} \Rightarrow B \geq\left(\frac{Z^{H}-Z^{L}}{2}\right)+\lambda^{D}-\left((1-\alpha)\left(X^{H}-I\right)\right) . \\
& (10) \geq(6) \text { if } \bar{Z}+(1-\alpha)\left(X^{H}-I\right)+B \geq Z^{H}+(1-\alpha) \lambda^{R} \Rightarrow B \geq\left(\frac{Z^{H}-Z^{L}}{2}\right)+(1-\alpha)\left(\lambda^{R}-\left(X^{H}-I\right)\right) .
\end{aligned}
$$

$(18) \geq(6)$ if $\lambda^{D} \geq(1-\alpha) \lambda^{R}$. 